1983

\title{
Freedom of Information in Canada
}

John D. McCamus

Osgoode Hall Law School of York University, jmccamus@osgoode.yorku.ca

\section{Source Publication:}

Government Publications Review. Volume 10, Issue 1 (1983), p. 51-60.

Follow this and additional works at: https://digitalcommons.osgoode.yorku.ca/scholarly_works c) $(i) \Theta \Theta$

This work is licensed under a Creative Commons Attribution-Noncommercial-No Derivative Works 4.0 License.

\section{Recommended Citation}

McCamus, John D. "Freedom of Information in Canada." Government Publications Review 10.1 (1983): 51-60.

This Article is brought to you for free and open access by the Faculty Scholarship at Osgoode Digital Commons. It has been accepted for inclusion in Articles \& Book Chapters by an authorized administrator of Osgoode Digital Commons. 


\title{
FREEDOM OF INFORMATION IN CANADA
}

\author{
JOHN D. McCAMUS* \\ Osgoode Hall Law School, York University, 4700 Keele Street, Downsview, Ontario, Canada M3J 2R5
}

\begin{abstract}
To the surprise of some, the Canadian federal government and four of the ten provinces recently have enacted freedom of information legislation. The evolution of the new national Access to Information Act and its provisions are discussed here together with relevant contemporary initiatives taken at the provincial level. There can be no doubt but that the new federal Canadian freedom of information scheme contains many features which will disappoint those who have advocated legislation of this kind. Nevertheless, it cannot be denied that the new Canadian statute, together with its provincial counterparts, constitute important and hopefully irreversible steps in the direction of a more open and accountable set of political institutions in Canada.
\end{abstract}

At first glance, Canada might be expected to be rather inhospitable terrain for freedom of information legislation [1]. The federal Parliament and the legislatures of the ten provinces are Westminster-style parliamentary governments. Members of the cabinet normally are drawn from those sitting members of the legislature who belong to the political party controlling a majority of the house. Party discipline requires backbenchers to offer unstinting support to the cabinet. Members of cabinet are responsible for the operation of the various departments and agencies of the federal government. Thus, in sharp contrast to the divisions inherent in the American separation of powers model, the Canadian system of government places effective control over both the executive and legislative branches of government in the hands of the Prime Minister and Cabinet. If the enactment of freedom of information legislation in the United States is to be explained in part by the existence of tension between the executive and legislative branches of government, such tension normally is

\footnotetext{
*Prof. McCamus is Dean of the Osgoode Hall Law School at York University. His published works include Freedom of Information: Canadian Perspectives (1981).
} 
absent in the Canadian context. Moreover, at the federal level, and in some of the provinces, at least one or another of the major political parties has dominated electoral politics for much of our re- cent history. For most of this century, for example, the federal Parliament has been con- trolled by the Liberal Party, with infrequent interludes of governance by the Progressive Conservative Party. Thus, whatever motivation there might otherwise be for a party in power to enact public access laws in the expectation that they might be of considerable use once the party again finds itself in opposition, also is typically absent. For these and other reasons, it is, therefore, somewhat surprising that in recent years, the Canadian federal government and four of the ten provinces Nova Scotia, New Brunswick, Newfoundland and Quebec-have enacted freedom of information legislation and that it has been promised by two more-Manitoba and Ontario.

It is perhaps less surprising that the gestation of this legislation at both the federal and provincial levels has been rather lengthy, notwithstanding the fact that the freedom of information concept has enjoyed reasonably energetic support from a broad cross-section of public opinion. No doubt influenced to a considerable extent by developments in the U.S., the idea has been vigorously advocated by members of opposition parties of whatever political stripe as well as by business and labour groups, the Canadian Bar Association [2], the Canadian Civil Liberties Association, and associations of academics and public interest groups of various kinds, including at least two that were created exclusively for the purpose of promoting access laws. Although government spokesmen at all levels have suggested from time to time that there is little public support for access legislation, it nonetheless remains true that this idea has enjoyed persistent support from a remarkably broad cross-section of groups and individuals. This fact, together with the special interest taken in the subject by the press, has kept the subject on the Canadian political agenda throughout the past decade. 


\section{HISTORICAL DEVELOPMENT}

Although academic interest in access legislation can be traced back to the mid '60s [3], serious political discussion of this subject did not begin at the federal level until 1973. In February of that year, the Liberal Government tabled in the House a cabinet directive titled "Notices of Motion for the Production of Papers" [4] in which the Government adopted a general policy concerning access to information by members of the House. Rather like the American Freedom of Information Act, the directive adopted the general principle of granting access to information unless the information came within one or more of the listed ex- emptions. Unlike the American Act, the directive imposed no binding obligation on the Government to disclose and made no provision for independent review of decisions to with- hold information. Later that year, a Private Members' bill setting forth a freedom of information scheme which had been introduced by Gerald Baldwin, M.P., the leading Conservative spokesman on the information issue, together with the cabinet directive, was referred to a parliamentary committee for its consideration. Referral of a Private Members' bill to committee is an unusual step in Canadian parliamentary practice and, therefore, was seen as a signal of serious governmental interest in the subject. The committee conducted extensive public hearings. Interestingly, the Government tabled before the committee a document pre- pared by Mr. D.F. Wall, one of its senior officials, titled "The Provision of Government In- formation" which was a report originally prepared for internal purposes, recommending the adoption of policies favouring much greater public access to government records [5]. This, too, suggested rowing support for the freedom of information idea in governmental ranks. In December 1975, the committee tabled its own report recommending the enactment of a freedom of information scheme. 
The response of the Liberal Government to this recommendation was not immediate. In June 1977, the then Secretary of State, the Hon. John Roberts, tabled a Green Paper espousing the general principle that "assessment of government depends on full understanding of the context in which decisions are made" [6] and exploring various areas of difficulty involved in the drafting of a freedom of information scheme. The Green Paper evidenced extreme sensitivity on the question of the review of decisions to deny access. The discussion in the Paper made a noble effort to undermine the suggestion offered by many others that the courts, as in the American scheme, should have the authority to overrule a governmental decision to refuse disclosure. The essence of the argument made on this point in the Green Paper and, indeed, by many federal and provincial spokesmen before and since, was that judicial review of decisions to deny access to government records would be inconsistent with

the constitutional convention of ministerial responsibility. This was, and remains, an interesting exercise in political rhetoric. Although there appears to be no merit whatsoever in the claim of inconsistency, governments have attempted to defend their tradition of refusing in- convenient disclosures under the guise of preserving our Parliamentary heritage. The constitutional reality, however, is that the convention of ministerial responsibility has nothing to do with the tradition of non-disclosure. On the contrary, the convention asserts that Ministers of the Crown are responsible individually and collectively to the Legislature for the administration of the executive branch of government [7]. The historical significance of a principle rendering the Ministers of the Crown accountable to the Legislature is obvious; it is also obvious, of course, that with the rise of political parties and acceptance of the principle of party solidarity, the accountability of the Cabinet to the Legislature is more a matter of

form than substance. Thus, more cynical observers argue that "ministerial responsibility" is a 
shopworn constitutional myth and that one of the very compelling arguments in favour of freedom of information laws in parliamentary jurisdictions is that it would restore a measure of that very kind of accountability that was originally secured by the convention of ministerial responsibility. With the publication of the Green Paper, the question of judicial review came to dominate public discussion of the freedom of information issue. Ultimately, in December 1977, the Green Paper itself was referred back to the same parliamentary commit- tee that had conducted the earlier hearings, for further study.

A related and very important development in July 1977 at the federal level was the enactment of The Canadian Human Rights Act [8] which contained, in Part IV, a scheme conferring broad rights of access to government files containing personal information as part of a privacy protection scheme. Ironically, it appears that no explicit connection was drawn be- tween this enactment and the general desirability of freedom of information laws. One of the most notable achievements of the 1966 American Act had been the granting of a right of access to information in government records concerning oneself. Consistent with the views stated in the Green Paper, Part IV did not grant a right to judicial review of decisions to deny access. Appeals could be taken by disappointed individuals to a Privacy Commissioner who was given the power only to investigate and recommend disclosure, the ultimate power to decide residing with the appropriate Minister. Nonetheless, the establishment of a functioning access scheme for personal records must be seen as an important step. Successful implementation of Part IV demonstrated that many of the most difficult administrative problems involved in an access scheme could be resolved without creating unbearable burdens on the various departments and agencies of the federal government.

\section{PROVINCIAL DEVELOPMENTS}


A number of initiatives were taken during this period at the provincial level. In March 1977, the government of Ontario appointed a Commission on Freedom of Information and Individual Privacy with the broad mandate to make recommendations with respect to the recognition of public rights of access to government information, as well as the protection of individual privacy. In two provinces, Nova Scotia and New Brunswick, government bills on freedom of information were introduced. On November 1, Nova Scotia enacted its Freedom of Information Act [9], the first legislation of its kind in the Commonwealth. The Nova Scotia Act was modest in its design. Rather than adopt the American pattern of a broad, general principle of access subject to certain exceptions, the Nova Scotia statute simply established a right of access to certain categories of information such as material describing the organisation, programmes, or policies of a department, final decisions of an administrative tribunal, and files containing personal information. Refusals to grant access could be appealed only to the legislature itself, a body controlled, of course, by the government that had already determined that the request for access should be denied.

In June 1978, however, the government of New Brunswick enacted a Right to Information Act [10] which, in the American manner, adopted a broad principle of public access and created rights of appeal to either the provincial Ombudsman or to the courts in disputed cases. Given the nature of the debate at the federal level, the latter point was of particular interest, all the more so inasmuch as the New Brunswick government itself had previously indicated that it felt that independent review of decisions to review disclosure would be "at odds with the Parliamentary system" [11]. Although enacted in 1978, the New Brunswick statute was not proclaimed in force until January 1, 1980. Since that time, three judicial decisions under the Act have been reported, in all of which the requester has enjoyed at least partial success [12]. The Province of Newfoundland, obviously much influenced by the New Brunswick experience, enacted its Freedom of Information Act [13] in June 1981 to come into effect on January 1, 1982, in terms very similar to those of the New 
Brunswick legislation.

An alternative to full judicial review of decisions to deny access was explored in two of the provinces. The Ontario Commission, after publishing a series of thirteen research papers, produced its final report in August 1980 [14]. The report recommended enactment of freedom of information and privacy protection legislation which would confer broad public rights of access to government records and suggested that an appeal from a denial of access should be taken to a Fair Information Practices Tribunal, with ultimate recourse to the courts on questions of law alone. Similar recommendations were made in a study commissioned by the government of the Province of Quebec [15]. Although draft legislation has not yet surfaced in Ontario, in June 1982, the Quebec National Assembly enacted a statute creating rights of access and establishing a review mechanism of this kind [16]. The provisions of the statute creating rights of access have not yet, however, been proclaimed in force.

\section{ESTABLISHING A FEDERAL LAW}

At the federal level, the leisurely pace of activity on this subject quickened during 1978 and 1979. The parliamentary committee, having again conducted extensive hearings, tabled a report in June of 1978 calling for the enactment of a freedom of information law. In the early months of 1979, The Law Reform Commission of Canada, a government advisory body then engaged in extensive review of the activities of federal administrative agencies, published a research paper recommending the enactment of an access scheme covering the activities of such agencies [17]. Finally, in the spring of 1979, public statements were made by the Liberal Government that a freedom of information law would be introduced in the near future [18]. The promised bill did not materialise prior to the fall of Prime Minister Trudeau's Liberal Government in the federal election of May 1979. The Conservative Leader, Mr. Clark, focused considerable attention on the freedom of information issue 
during the election campaign and in October 1979, the newly-elected Conservative Government tabled its promised freedom of information legislation [19], together with a Privacy Protection Act which would have effected substantial revisions to Part IV of The Canadian Human Rights Act. The Conservative bill was similar in its essentials to American national freedom of information and privacy laws. It provided for a general principle of access subject to a more-or-less recognisable list of exemptions, together with access and correction rights relating to personal information. Most importantly, the Conservative bill provided for judicial review of government decisions to refuse access. Together with the proposed legislation, the Conservative Government tabled a series of cabinet discussion papers on which the bill was said to be based, and indicated that this kind of material would be routinely made available under the proposed legislation. Although the short-lived Conservative Government fell before this legislation was enacted, there can be little doubt that the popularity of this Conservative initiative added to the pressure for some action on this question on the re- elected Liberal Government.

Federal freedom of information legislation was promised by the re-elected Trudeau government in the Speech From the Throne of April 14, 1980, and ultimately, on July 17, 1980, Bill C-43 [20], a somewhat reworked version of the earlier Conservative bill, was given first reading. The passage of the bill through the House proved to be both prolonged and controversial. Committee hearings which began in March of 1981 continued on and off for more than a year and, in early 1982, it was widely rumoured that the government would not proceed with the bill. Ultimately, however, after revising some features of the bill, C-43 was enacted on June 28, 1982 and, although not yet proclaimed in force, it is anticipated that once regulations have been drafted and appropriate administrative arrangements for implementation have been made, the new Canadian Access to Information Act [21] will be brought into force. 


\section{THE NEW LAW}

In its essential features, the Canadian Act is similar to American national freedom of information and privacy laws. A broad right of public access, in the sense of allowing individuals an opportunity to examine a record or obtain a copy thereof, is conferred, subject to a list of exemptions. The government is under an obligation to make reasonable efforts to sever exempt from non-exempt material and to disclose the latter. Requests for access must receive a response within a statutory time limit. Requestors may be charged fees for the cost of reproduction and, in some cases, search time. Decisions to deny access are subject to initial review by an Information Commissioner, but ultimately may be appealed to the courts, although, as will be seen, this right is restricted with respect to certain of the exemptions.

In contrast to the American legislation, the drafting style of the Canadian statute is rather prolix. The Access to Information Act ultimately will occupy some fifty-odd pages of the federal statute book. Further, there are a number of respects in which the Canadian statute departs from the American model and offers some evidence of the nature of the political culture within which it was produced. Thus, access is to be granted in either of Canada's official languages in any case where a translation of the document exists or where it is deemed to be in the public interest that a translation be made. Perhaps the most important evidence of the Canadian flavour of the statute is to be found in the provisions exempting certain records from disclosure.

Although the Canadian Act contains exemptions pertaining to international affairs and defence, records containing advice or recommendations, material withheld under other statutes, trade secrets and other confidential commercial information, solicitor-client privilege, personal information, and law enforcement records [22], which are roughly analogous to the first seven exemptions of the American Act, the drafting of each provision 
is less biased in favour of disclosure than the equivalent provision of the American Act. In addition, the Canadian Act contains a substantial number of additional exemptions, some of which reflect the peculiar nature of Canadian political institutions and some others which appear to represent attempts to learn from and improve upon American experience with access legislation. It may be useful to illustrate some of these points.

Quite apart from the exemption for material containing advice or recommendations, the Canadian Act includes a comprehensive exemption of virtually all cabinet records, including "memoranda the purpose of which is to present proposals or recommendations" to the cabinet [23]. If broadly construed, it is obvious that the exemption of these records effects a wholesale exclusion of material, whether or not factual in nature, related to policymaking processes. Although cabinet secrecy is often defended in parliamentary jurisdictions on grounds of high constitutional principle, it is obvious that this provision simply reflects the desire of the inner circle of the government to immunize itself completely from the inconvenience and potential embarrassment of disclosures under the access scheme. The provision of the statute stipulates that the Act does not "apply" to cabinet records. Accordingly, cabinet records are not subject to the severability rule. Further, under related legislation, the government has given itself an unreviewable right to refuse to disclose cabinet records to a court [24]. Ironically, in the course of introducing its new freedom of information scheme, the Canadian government has enacted one of the most secretive executive privilege rules to be found in the western world.

The Canadian Act also has an explicit exemption for material the disclosure of which reasonably could be expected to be injurious to the federal government's ability to conduct federal-provincial affairs [25]. As Canadian governments at both the federal and provincial levels have long-established practices of secrecy with respect to federal-provincial dealings, it is reasonable to anticipate that much information relating to intergovernmental contact will 
be withheld under this provision. Although federal relations in the Canadian polity are made more difficult by the presence of a small number of very large provincial units and, at the present time, by the fact that one of these provinces, Quebec, is governed by a party committed to the separation of that province from the federal state, it is difficult to defend so comprehensive an exemption. Obviously, if broadly construed, this provision will permit the withholding of a vast and important body of government information.

The Canadian Act also contains generous exemptions relating to government proprietary information [26] which have no counterpart in the American legislation. This no doubt reflects, in part, the much more important role played in Canada by public enterprise. Even prior to the recent and substantial intervention of public enterprise in the resources sector, the total revenue of federal and provincial Crown corporations had been estimated at approximately $10 \%$ of Canada's gross national product [27]. The most important of the federally-chartered commercial Crown corporations simply are exempted from the new Canadian access scheme. Those few covered by the scheme, however, will find that information which they would normally treat as confidential will be quite adequately protected by appropriate exemptions.

A number of the exempting provisions included in the statute evidently constitute attempts to learn from what public officials at least would view as deficiencies in the American scheme. Thus, the exemption for law enforcement material permits, in the American manner, the withholding of information the disclosure of which could reasonably be expected to be injurious to law enforcement activities. In addition, however, the Act confers upon the government the power to exempt by regulation the investigative records of any law enforcement body [28]. It remains to be seen which bodies will be so exempted, but it may safely be assumed that the power to exempt by regulation is the Canadian response to the practical problems encountered under the American Act by federal law enforcement and security agencies.

The disclosure of personal data concerning identifiable individuals is an obvious point of 
difficulty under a freedom of information scheme. The American Act exempts such data where disclosure would amount to a "clearly unwarranted invasion of personal privacy" and thus requires a balancing of the disclosure and privacy interests arising in the context of each request. The Canadian scheme approaches this problem by simply exempting almost all personal data from the access scheme [29] and then by conferring on the government what is essentially an unreviewable discretion to disclose personal data in the context of the new privacy protection legislation. The Canadian Act thus has avoided the alleged uncertainties of the American balancing test, but does so at the cost of transporting another rather substantial percentage of government record holdings into the realm of discretionary disclosure.

Canadian officials often have been surprised to learn that information disclosed in confidence by Canadian agencies to their American counterparts might be disclosed under the American access scheme. No reciprocal difficulty will arise under the Canadian Act, however, as a broad exemption for confidential intergovernmental disclosures has been included in the statute [30]. The provision protects international exchanges of information as well as exchanges between various levels of government within Canada. Again, this is a pro- vision which is capable of shielding a vast body of information in a federal state. However, it will eliminate a practical problem inherent in the American scheme which, indeed, has surfaced in the American case law [31].

In its exemption for international affairs and defence, the Canadian Act departs from the American model by explicitly setting forth the criteria for exemption in the statute itself. The American Act, it will be recalled, simply exempts material which has been classified properly by executive order. The Canadian provision is thought to be an improvement inasmuch as disclosure under the statute will operate quite independently of any classification system put in place by the executive or any changes made to the system from time to time. This benefit may be an illusory one, however, in that the American system of classification and declassification of documents has been, and probably will remain, more conducive to disclosure than the 
Canadian statutory provision [32].

A number of other minor exemptions could be mentioned, but perhaps the case has been made that the Canadian scheme appears to have been drafted in a frame of mind which essentially was sympathetic to past practices of government secrecy and confidentiality [33]. Accordingly, it may well be that the most important features of the scheme will be those which create informal pressures in favour of disclosure. From this point of view, the office of the Information Commissioner may prove to be instrumental in any success the new legislation achieves in promoting the disclosure of government information to the public. Individuals who have been denied access may request a review of this decision by the Commissioner, who must in turn investigate the complaint and make a recommendation as to whether or not the record should be disclosed. Although the Commissioner has no power to order disclosure, extensive investigatory powers are conferred by the statute, including the power to examine any record to which the Act applies [34].

The role of the Information Commissioner thus will be very similar to that of the Privacy Commissioner under Part IV of The Canadian Human Rights Act. The current incumbent of the latter position, Inger Hansen, attributes much of her success in promoting access to the fact that her incapacity to make binding orders has encouraged public officials to deal with her in a more open and cooperative fashion than might be expected [35]. One may be encouraged to hope, therefore, that the Information Commissioner under the new scheme will be able to assist in the creation of an environment within which public officials will generously construe the rights of access created by the scheme.

If the Commissioner's investigation does not result in disclosure of the requested document, the disappointed individual may pursue further appeal to the Federal Court of Canada. The Court does have the power to order disclosure, but the scope of the Court's ability to review decisions to deny access is subject to two important restrictions. First, as has been mentioned above, the Court has no power to review a decision taken by a cabinet official to 
refuse to disclose cabinet records. The Act is said not to "apply" to cabinet records and this, together with the fact that collateral legislation permits a Minister to exercise a unilateral right to withhold cabinet records from judicial proceedings, means that the government has retained an unreviewable discretion to classify documents as cabinet records and thereby lift them out of the statutory scheme. With respect to records covered by the statute, however, a second limitation on judicial review is imposed. In the case of five exemptions -those relating to federal-provincial relations, international affairs and defence, law enforcement, the security of penal institutions, and the financial interests of the Government of Canadathe scope of review is limited to a determination of whether or not the head of the institution refusing disclosure had "reasonable grounds" on which to refuse disclosure of the record. Thus, in the context of law enforcement for example, the Court cannot make an independent judgment as to whether or not disclosure reasonably would be expected to be injurious to law enforcement, but must defer to the decision of the public official in question if satisfied that the official had reasonable grounds for the decision to deny access [36]. With respect to other exemptions, however, the scope of judicial review is unrestricted and will operate, presumably, more or less in the fashion that it has under the American Act.

An interesting feature of the procedures for review is that the Canadian statute confers procedural and substantive rights on so-called third parties, i.e., private individuals whose personal information is contained in a government record which the government proposes to disclose, or commercial firms whose proprietary information is the subject of a proposed disclosure. Third parties are entitled to timely notice of a decision to disclose, and may intervene in or indeed initiate review procedures at the Information Commissioner or Federal Court level. The exemptions for personal information and commercially valuable information are mandatory in the sense that the government must refuse to disclose an exempt record and third parties, therefore, have a substantive right to seek to enjoin disclosure in the Federal Court. As has been indicated above, very little personal information potentially is accessible 
under the Act. Access will be given only to certain basic information concerning the status of public servants and consultants and the identity of recipients of government licences and other forms of largesse. Disputes concerning access to personal data, therefore, are not likely to produce much three party litigation. In the commercial context, however, the prospects for access are much greater and the likelihood of substantial third party litigation more real. No doubt, the Federal Court of Canada will be called upon with some frequency to determine the kinds of information which, if disclosed, "could reasonably be expected to result in material financial loss or gain to, or could reasonably be expected to prejudice the competitive position of, a third party" [37].

Apart from the conferral of access rights, the Canadian Act does impose affirmative obligations to publish certain kinds of material or otherwise make information available to members of the public. Again, however, the Canadian scheme is more modest in these respects than its American counterpart. One of the great triumphs of the American scheme, as far as administrative lawyers are concerned, is that it requires the publication and indexing of the so-called "secret law" of the federal agencies. Under the Canadian scheme, agencies are required only to make available at their headquarters any manuals used by their employees in carrying out their programmes. The statute, however, does impose an affirmative obligation to publish certain other kinds of information which will be of assistance to individuals seeking access to information under the Canadian scheme. Indeed, the rather ambitious requirement that government institutions publish "a description of all classes of records under the control of each government institution in sufficient detail to facilitate the exercise of the right of access under this Act" will impose substantial burdens on the information systems personnel of the federal government [38].

\section{OVERVIEW}


There can be no doubt but that the new Canadian federal freedom of information scheme contains many features which will disappoint those who have advocated legislation of this kind. However, given the structural realities of Canadian politics and the deeply-entrenched traditions of government secrecy, it must be said that it is, to some extent, remarkable that legislation of this kind has been enacted at all. Some will attribute this limited degree of success to the power of a great idea, or to the continuing vitality of democratic ideals in the Canadian political culture. Others, I suspect, will see the Canadian flirtation with freedom of information schemes at both federal and provincial levels as enduring evidence of the profound influence of American political fashion on Canadian political life. Whatever its political root, however, and despite the fact that the Canadian embrace of the freedom of information concept does seem rather tentative, the new Canadian statute, together with its provincial counterparts, constitute, in my view, important and hopefully irreversible steps in the direction of a more open and accountable set of political institutions in Canada.

\section{NOTES AND REFERENCES}

I. See, generally, D.C. Rowat, "Canada" in D.C. Rowat, ed. Administrative Secrecy in Developed Countries. New York: Columbia University Press, 1979, pp. 279-308.

2. Two C.B.A. publications have been influential. See T.M. Rankin. Freedom of Information: Will the Doors Stay Shut? Ottawa: Canadian Bar Association, 1977; Canadian Bar Association. Freedom of Information in Canada, a Model Bill. Ottawa: Canadian Bar Association, 1979.

3. See, e.g., D.C. Rowat. "How Much Administrative Secrecy?" Canadian Journal of Economics and Political Science 31 (November 1965), 479-498.

4. The directive is reproduced in Department of the Secretary of State. Legislation on Public Access to Government Documents. Ottawa: Supply and Services Canada, 1977, p. 31.

5. Canada, Parliament, First Session, Thirtieth Parliament, 1974-75. Standing Joint Committee on Regulations and other Statutory Instruments, Minutes of Proceedings and Evidence. Issue No. 32. Ottawa, 1975, 30-71 .

6. Supra, note 3 , at 1 .

7. For useful discussion, see, Commission on Freedom of Information and Individual Privacy, Final Report: Public Government for Private People, Vol. II. Toronto: Queens Printer of Ontario, 1980, pp. 83-95.

8. S.C., 1976-77, c. 33 .

9. S.N.S. 1977, c. 10, for a discussion of which, see K.R. Evans. "Nova Scotia Freedom of Information Act." Dalhousie Law Journal 5 (May 1979), 494-504.

10. S.N.B. 1978, c. R-10.3, as amended by S.N.B. 1979, c. 41, for a discussion of which, see B.G. Smith, "The New Brunswick Right to Information Act" in J.D. McCamus, ed. Freedom of Information: Canadian Perspectives. Toronto, Butterworths, 1981, p. 213.

11. New Brunswick, Legislative Assembly. Freedom of Information: Outline of Policy Pertaining to a Legislated Right of Access by the Public to Government Documents. Fredericton, June 1977, at p. 32 (tabled in the Assembly by the Premier).

12. Re Daigle (1980) 30 N.B.R. (2d) 209 (Consultants' assessment of government construction project); Re McKay (1981), 35 N.B.R. (2d) 4050 (Financial Reports relating to budget formulation); Gillis v. Chairman of The New Brunswick Electric Power Commission (1982) 37 N.B.R. (2d) 66 (Information concerning Government construction contracts entered into with competitors of requestor).

13. S. Nfld. 1981, c. 5. 
14. Supra, note 7.

15. Commission d'etude sur l'acces du citoyen l'information gouvernementale et sur la protection des renseignements personnels. Information et liberte. Quebec, Gouvernement du Quebec, 1981.

16. Quebec, National Assembly of Quebec, 3rd Session Thirty-second Legislature, 1982. Bill 65, An Act Respecting Access to Documents Held by Public Bodies and the Protection of Personal Information.

17. R.T. Franson. Access to Information: Independent Administrative Agencies. Ottawa: Law Reform Commission of Canada, 1979.

18. Canada, Secretary of State. "Notes for an address by The Hon. John Roberts, Secretary of State of Canada, to the National Conference on Freeman of Information." University of Victoria, Friday, March 23, 1979.

19. Canada, Parliament, First Session, Thirty-first Parliament, 1979, House of Commons. Bill C-15, "An Act to extend the present laws of Canada that provide access to information under the control of the Government of Canada and to amend the Canada Evidence Act, the Federal Court Act and the Statutory Instruments Act ."

20. Canada, Parliament, First Session, Thirty-second Parliament, 1980, House of Commons. Bill C-43, "An Act to enact the Access to Information Act and the Privacy Act, to amend the Federal Court Act and the Canada Evidence Act, and to amend certain other Acts in consequence thereof."

21. Canada, Parliament, First Session, Thirty-second Parliament, 1980, House of Commons. Bill C-43, "An Act to enact the Access to Information Act and the Privacy Act, to amend the Federal Court Act and the Canada Evidence Act, and to amend certain other Acts in consequence thereof, as passed by the House of Commons, June 28, 1982, Schedule I."

22. Ibid., secs. $15,21,24,20,23,19$, and 16 , respectively.

23. Ibid., sec. 69.

24. Ibid., sched. Ill, sec. 36.3 .

25. Ibid. sec. 14 .

26. Ibid. sec. 18 .

27. I.A. Litvak. Information, Access and Crown Corporations. Ontario: Commission on Freedom of Information and Individual Privacy, 1980, p. 2.

28. Supra, note 21 , sec. 16 (I) (a).

29. Ibid., sec. 19.

30. Ibid., sec. 13 .

31. Consider, for example, the controversy concerning the accessibility of pre-sentence reports once in the hands of a federal agency. See, Cook v. Willingham, 400 F. 2d 885 (10th Cir. 1968); United States v. Dingle, 546 F. 2d 1378 (10th Cir. 1976); Smith v. Flaherty, 465 F. Supp. 815 (M.D. Pa. 1978).

32. See, D.C. Rowat. "Canada's Security Classification System and a Freedom of Information Act" in McCamus, ed., supra, note IO, p. 167.

33. For a more extended discussion, see J.D. McCamus, "Bill C-43: The Federal Canadian Proposals of 1980" in McCamus, ed., supra, note 10, 266-305.

34. Supra, note 21 , sec. 36.

35. See, I. Hansen, "The Canadian Human Rights Act, Part IV" in McCamus, ed., supra, note 10 at p. 249.

36. Supra, note 21 , sec. 50 .

37. Ibid., sec. 2 (I) (c).

38. Ibid., sec. 5 . 